\title{
Chronic orbital inflammatory disease: parasitisation of orbital leucocytes by mollicute-like organisms
}

\author{
EMIL WIROSTKO,' LEWIS JOHNSON, ${ }^{2}$ AND BARBARA WIROSTKO
}

From the ${ }^{\prime}$ Edward $S$ Harkness Eye Institute and the ${ }^{2}$ Department of Pathology, Columbia-Presbyterian Medical Center, New York, and the ${ }^{3}$ College of Physicians and Surgeons, Columbia University, New York, USA

SUMMARY Chronic orbital inflammatory disease (COID) is usually considered non-infectious and idiopathic. Treatment is empirical, palliative, and may not prevent disease progression. COID occurs in isolation or in association with various systemic diseases. Exophthalmos may be an important presenting sign. Vasculitis, lymphoid infiltrates, and granulomas are common. Mollicute-like organisms (MLO) parasitising and destroying vitreous leucocytes are often found to cause human chronic uveitis when an appropriate search is made. Inoculation of these MLO into mouse eyelids produced chronic uveitis and exophthalmic orbital inflammatory disease. Mollicutes are cell wall deficient bacteria. Extracellular mollicutes cause human and animal diseases characterised by lymphoid infiltrates, immunosuppresssion, and autoantibody production. Intracellular morphologically similar bacteria are non-cultivable pathogens termed MLO. Identification is based on direct detection in diseased cells by transmission electron microscopy. MLO are cytopathogenic and detection is aided by the alterations they produce. MLO replace the cytoplasm, destroy the organelles, and alter the nucleus. This results in cell proliferation, destruction, and dysfunction. MLO parasitise lymphocytes, monocytes, and polymorphonuclear leucocytes. This report describes orbital leucocytes parasitised by MLO in three patients with isolated COID. Rifampicin treatment of MLO disease is discussed.

Chronic orbital inflammatory disease (COID) is usually considered to be non-infectious and idiopathic.' It occurs in isolation or in association with various systemic diseases.' Exophthalmos may be an important presenting sign. ${ }^{1}$ Vasculitis, lymphoid infiltrates, and granuloma formation are common pathological features.' Mollicute-like organisms (MLO) parasitising and destroying vitreous leucocytes are often found to cause chronic uveitis in patients when an appropriate search is made. ${ }^{2-\phi}$ Inoculation of these MLO into mouse eyelids produced chronic uveitis ${ }^{7}$ and exophthalmic orbital inflammatory disease. ${ }^{8}$ MLO became disseminated to produce lethal chronic inflammatory disease in all organs. ${ }^{7-10}$ MLO-parasitised leucocytes were detected in all the diseased organs. ${ }^{7-10}$ The disease was progressive and similar in all the organs..$^{711}$ The initial lesion was a vasculitis. ${ }^{710}$ This led to tissue lysis, lymphoid infiltrates, and granuloma formation. ${ }^{7-11}$

Correspondence to Emil Wirostko, MD, Edward S Harkness Eye Institute. Columbia-Presbyterian medical Center, 635 West 165th Street, New York, NY 10032, USA.
Mollicutes are cell-wall-deficient bacteria." They can be overlooked or confused with viruses. ${ }^{1213}$ Their ultrastructural appearance ${ }^{1+}$ is characteristic. Extracellular mollicutes are fastidious, ${ }^{15}$ lipid-rich, ${ }^{16}$ and contain a variety of potent cytotoxic substances including nucleases. ${ }^{17}$ Extracellular mollicutes cause human and animal diseases characterised by lymphoid infiltrates, immunosuppression, and autoantibody production. ${ }^{17-20}$

Some morphologically similar organisms are intracellular pathogens. ${ }^{2-6} 1321-24$ Despite considerable efforts at cultivation by many investigators the consensus is that these mollicute forms are noncultivable. . $^{2-132122}$ Their taxonomy is uncertain and they are termed MLO. ${ }^{13}$ Identification of MLO is based on direct detection within parasitised cells by transmission electron microscopy. $.^{2-6} 1321-24$ MLO are cytopathogenic and their detection is aided by the ultrastructural alterations they produce. They replace the cytoplasm and destroy the organelles,,$^{2-\infty 2123}$ and they also alter the nucleus, probably as a result of nuclear parasitisation ${ }^{2-623}$ and release of nuclease..$^{24}$ 
This results in cell proliferation, destruction, and dysfunction. ${ }^{13}$ A common and important feature of MLO disease is vascular involvement. ${ }^{7-111} 1321$

MLO parasitise lymphocytes, ${ }^{+}$monocytes, ${ }^{5}$ and polymorphonuclear leucocytes. They appear as undulating filaments of $0 \cdot 005-0.01 \mu \mathrm{m}$ diameter, and pleomorphic trilaminar membrane-bound $0 \cdot 01-1 \cdot 0$ $\mu \mathrm{m}$ tubulospherical bodies. Some forms develop into spore-like $0.5-0.7 \mu \mathrm{m}$ cocci by deposition of electron dense material within the trilaminar membrane. ${ }^{3}$ The cocci have distinctive ultrastructural features. ${ }^{23}$ The following report describes the results of a search for MLO parasitised leucocytes in the orbital tissues of patients with isolated COID.

\section{Materials and methods}

Three patients with COID served as sources of the study materials. None had a history of thyroid, bowel, or other systemic disease. On physical examination all had normal signs and no evidence of peripheral lymphadenopathy. The results of routine studies of urine, blood cells and chemistry, and thyroid function were within normal limits in all three, and the chest roentgenogram of each was normal. The COID of each patient was considered to be non-infectious. ' Microbiological studies were not conducted on the excised orbital tissues.

Patient 1 was a 17 -year-old female with a two-year history of progressive left upper eyelid ptosis. Orbital computed axial tomograms were normal. Two separate attempts at surgical correction were initially successful, but there was gradual return of the ptosis. During a third corrective procedure abnormal orbital tissue was noted and excised.

Patient 2 was a 61-year-old female with a six-year history of progressive exophthalmos limited to the right orbit. Computed axial tomograms performed at the onset of the disease showed right orbital patchy non-confluent radiodensities and normal extraocular muscles. The left orbit was normal. Biopsy then showed chronic non-specific inflammation. Treatment at that time consisted of combination radiation and chemotherapy. This arrested the disease, but five years later progressive exophthalmos recurred. A repeated computed axial tomography displayed progression of the right orbital disease. The contralateral orbit was again normal. A biopsy of the diseased tissue was taken, and that material was studied in this report.

Patient 3 was a 65-year-old female with a fivemonth history of progressive exophthalmos of the right orbit. Computed axial tomograms showed patchy right orbital non-confluent radiodensities and normal extraocular muscles. The contralateral orbit was normal. An orbital biopsy was performed.

A portion of each patient's specimen was fixed in $10 \%$ formalin, processed for routine paraffinembedded histological sections, and stained with haematoxylin-eosin. Another portion of each patient's specimen was finely minced, fixed in 150 $\mathrm{mM}$ cacodylate buffered $2 \%$ glutaraldehyde, post-
Fig. 1 Case 1. Chronic vasculitis involving arterioles, capillaries, and adventitia of small arteries. (Haematoxylin-eosin, $\times 110)$.

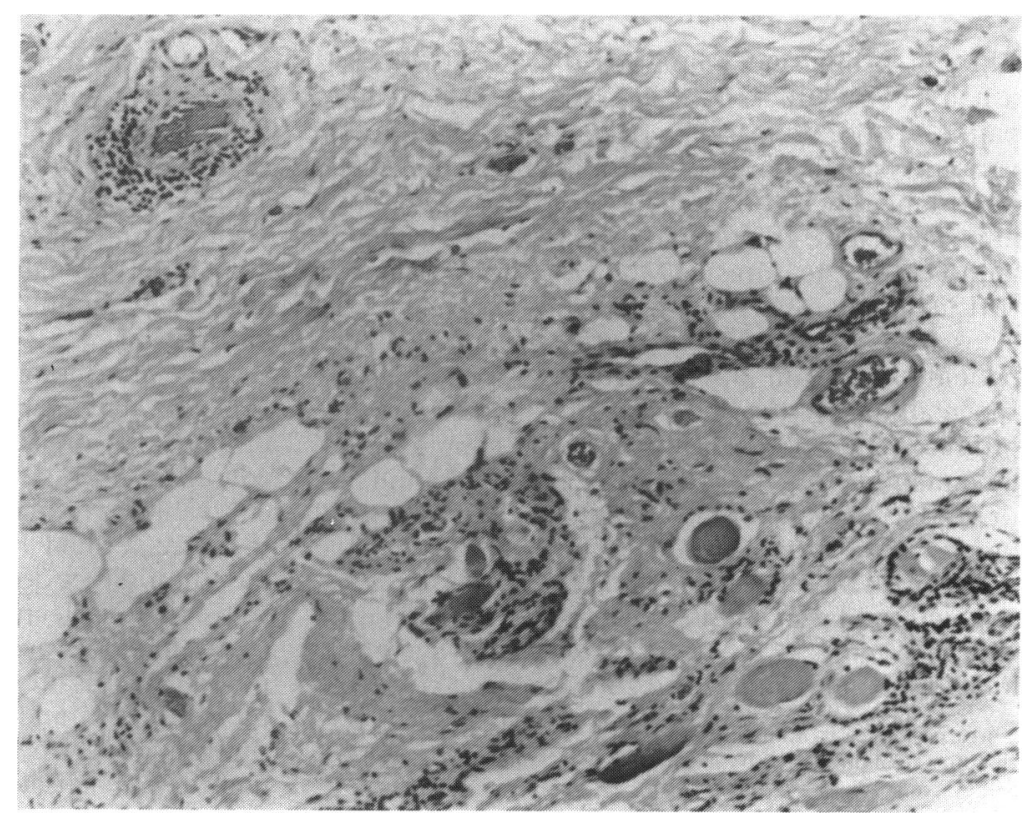


fixed in osmium tetroxide, and embedded in Araldite (R). All these materials were available for investigational purposes through an Institutional Review Board exempt protocol. The sections stained with haematoxylin-eosin were studied for COID diagnostic concurrence under a light microscope. Thick sections embedded in Araldite (R) and stained with toluidine blue were also studied for leucocyte-rich foci under a light microscope. Multiple ultrathin sections were prepared from such foci and stained with uranyl acetate-lead citrate. All available leucocytes in these sections were studied for leucocyte alterations and MLO parasitisation by a transmission electron microscope.

\section{Results}

\section{HISTOLOGICAL STUDIES}

The numbers of leucocytes varied on each patient's specimen (Figs. 1-3). Lymphocytes were the predominant leucocyte in each specimen, but a few scattered monocytes and polymorphonuclear leucocytes were also present. Vasculitis was detected in each specimen, but it was most evident in the specimen from patient 1 (Fig. 1). Each specimen also showed scattered minute lytic foci in the extravascular adipose tissue. The specimen from patient 2 showed an intense diffuse lymphoid infiltrate (Fig. 2 ). The specimen from patient 3 showed several nonnecrotic, non-confluent, epithelioid granulomas interspersed between focally intense lymphoid infiltrates (Fig. 3). Ziehl-Nielsen, Gomori's metha-

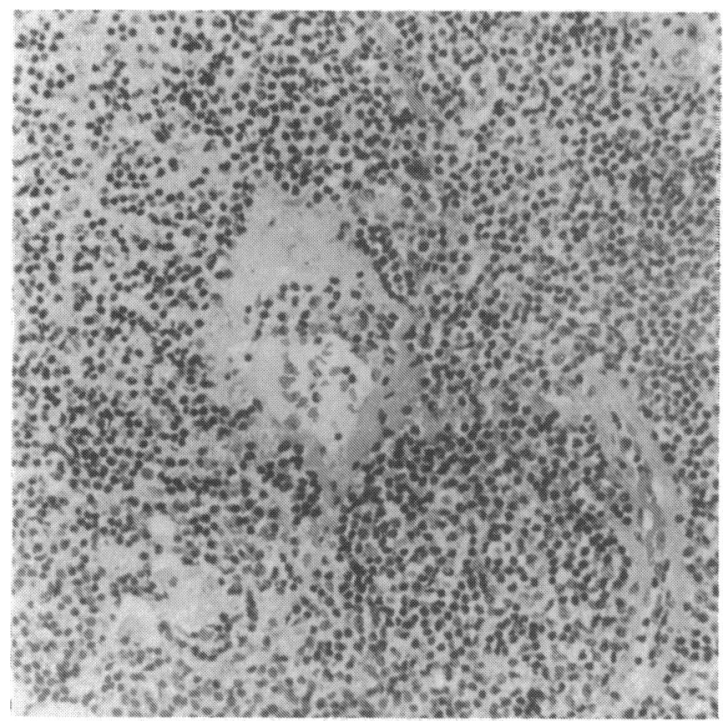

Fig. 2 Case 2. A diffuse lymphocytic infiltrate; an inflamed arteriole is also detectable. (Haematoxylin-eosin, $\times 155)$.

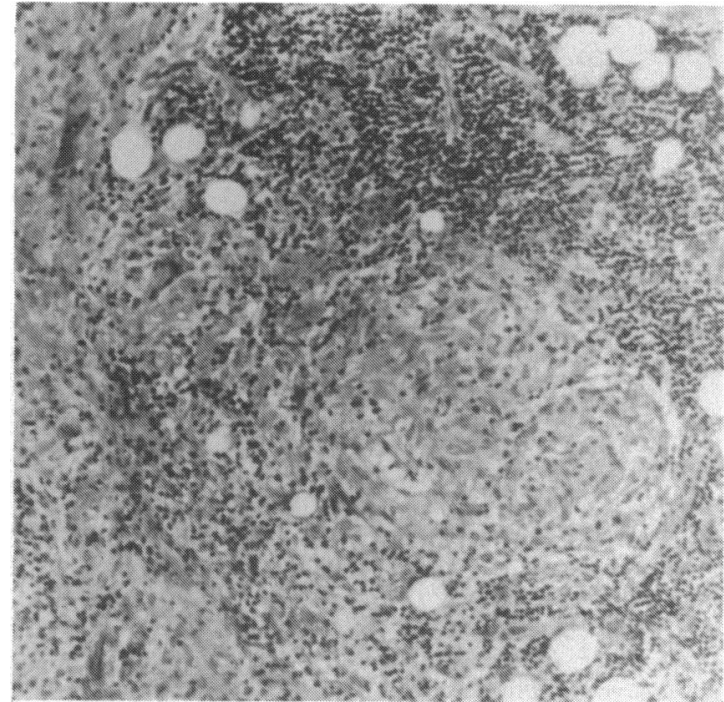

Fig. 3 Case 3. Non-necrotic epithelioid granuloma, a lymphocytic infiltrate, and fibrosis. No acid fast bacilli or fungi were detected in this specimen. (Haematoxylin-eosin, $\times 100)$.

namine silver, and periodic acid Schiff stains on this specimen were negative for acid fast bacilli and fungi.

TRANSMISSION ELECTRON MICROSCOPIC STUDIES

About $2-10 \%$ of all the leucocytes in each patient's specimen displayed intracytoplasmic undulating filaments, $0.005-0.01 \mu \mathrm{m}$ diameter, and pleomorphic trilaminar membrane-bound $0.01-1.0 \mu \mathrm{m}$ tubulospherical bodies (Figs. 4,5). Some of these bodies exhibited deposition of intramembranous electron dense material to form $0.5-0.7 \mu \mathrm{m}$ cocci (Fig. 5). All these cocci had thick cell walls, a distinct periplasm, and complex internal tubulofilamentous substructures. Nuclei of leucocytes harbouring the abnormal bodies often had ragged, irregular contours, chromatin clumping with lysis, and prominent perinuclear electron lucency (Figs. 4,5). In the polymorphonuclear leucocytes these bodies were usually associated with cytoskeletal lysis and a paucity of normal granules (Fig. 5).

\section{Discussion}

This study shows the diagnostic value of examining leucocyte COID lesions by transmission electron microscopy. Clinically and pathologically each patient's disease was considered to be non-infectious and idiopathic.' However, the leucocytes in each specimen contained intracytoplasmic bacterialike bodies. Most of these lacked a cell wall. Some 
Fig. 4 An aggregate of undulating tubules replaces the cytoplasm on the right. The remaining cytoplasm appears normal. A prominent flask shaped body (arrow) with a distinctive limiting membrane and complex internal substructures is also apparent. The nucleus shows diffusely dense chromatin, a markedly irregular contour, and a prominent perinuclear electronlucent halo. (Uranyl acetate-lead citrate, $\times 53300)$.

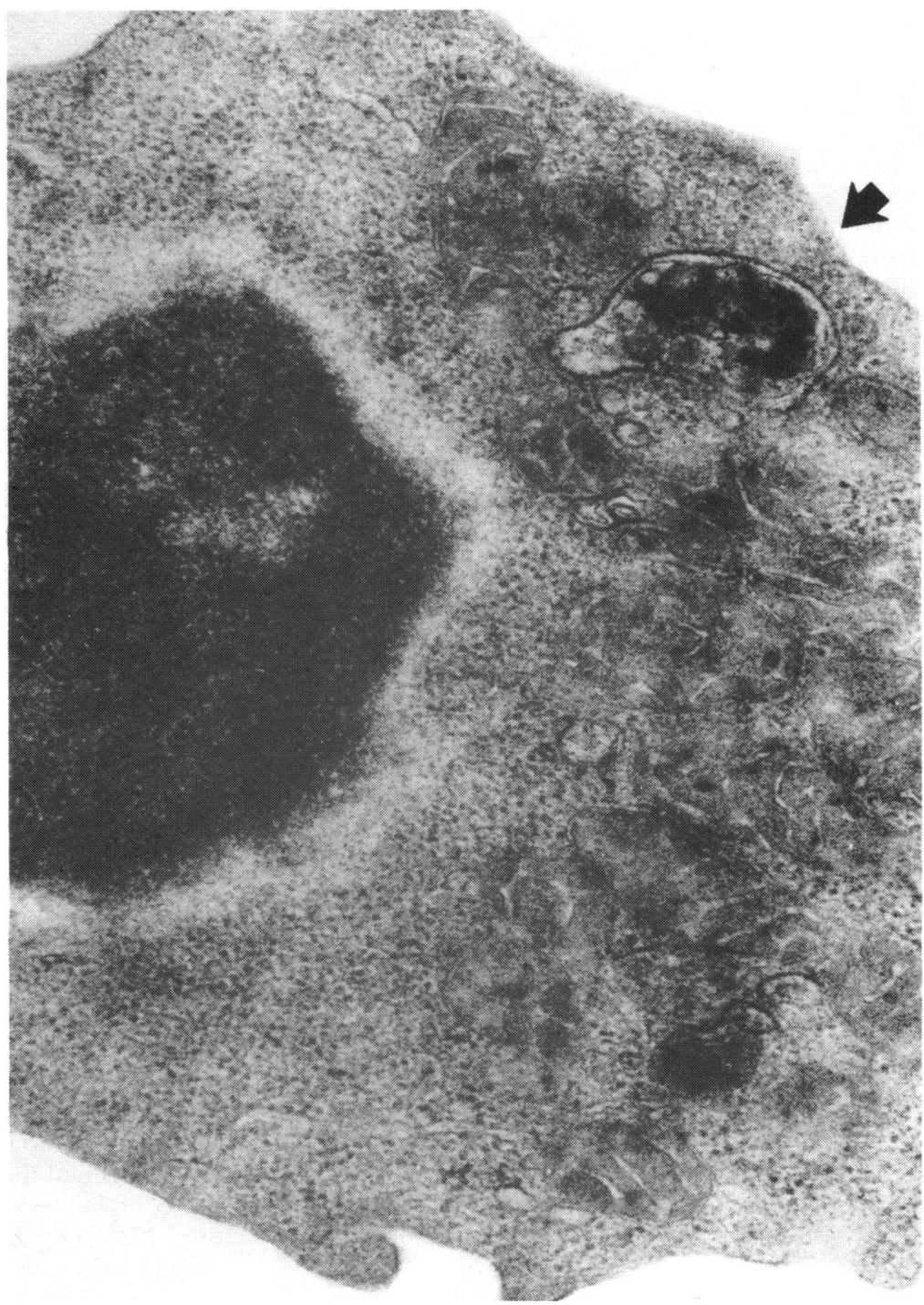

of these forms elaborated distinctive spore-like cocci. The organisms were morphologically indistinguishable from the MLO that produced chronic orbital inflammatory disease in mice. ${ }^{2-5}$ they produced nuclear and cytoplasmic alterations similar to those caused by the other MLO. ${ }^{2-5}$ They parasitised a similar wide range of leucocyte cell lines. ${ }^{2-5} \mathrm{We}$ believe that these bacteria were MLO and caused the COID in these patients.

Study of polymorphonuclear leucocytes facilitates MLO detection. As in other chronic inflammatory diseases, ${ }^{.5}$ polymorphonuclear leucocytes are present in MLO diseases. " Prominent cytoplasmic lysis occurs in these leucocytes as a result of MLO parasitisation. " The smallest MLO particles, namely, the 0.005-0.01 $\mu \mathrm{m}$ diameter filaments, are readily detected in the lysed cytoplasm. " Furthermore, cell wall material forming distinctive spore-like cocci is often deposited in these cells. ${ }^{2 n}$ The lipid rich polymorphonuclear leucocyte cytoplasm ${ }^{26}$ may enhance MLO growth and development. ${ }^{\prime}$

Chronicity was a noteworthy clinical feature of the MLO orbital disease in all three patients. Progression to exophthalmos occurred in two of them. All had chronic inflammation with various features including vasculitis, tissue lysis, lymphoid infiltrates, and 


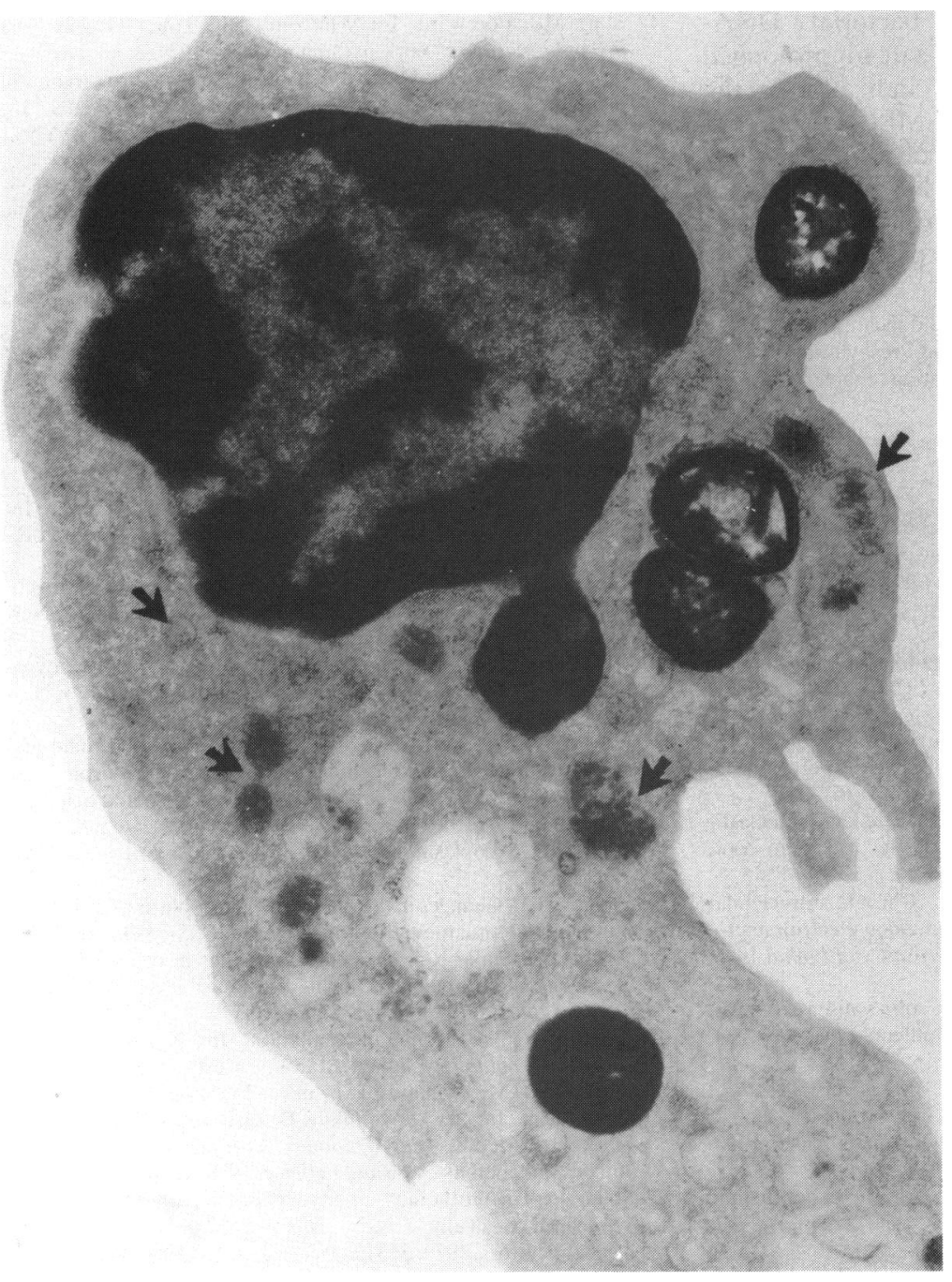

Fig. 5 Several spore-like cocci are apparent. Undulating pleomorphic tubulospherical bodies (arrows), some with internal structures, are also detectable. The cytoplasm shows patchy lysis and a paucity of normal granules. The nucleus displays several electron lucent chromatin foci of 'moth eaten' appearance, a ragged irregular contour, and a perinuclear electron lucent halo. (Uranyl acetate-lead citrate, $\times 20900)$.

granuloma formation. In the mouse orbit MLO inoculation produced similar chronic inflammation. ${ }^{8}$ The mouse disease was progressive, leading to exophthalmos, and vasculitis of small vessels was the initial lesion. ${ }^{x}$ The mouse MLO orbital inflammatory process resulted in tissue lysis, lymphoid infiltrates, and granuloma formation. ${ }^{8}$ Disease chronicity and progression in the mouse was attributed to MLO disruption of the host inflammatory process. ${ }^{x}{ }^{10}$

MLO were found in all three patients studied. A search for MLO as a cause of COID in other healthy patients needs to be conducted to expand these observations. Moreover, the results of MLO experimental mouse disease suggest that MLO may be a cause of human idiopathic systemic inflammatory diseases in addition to orbital disease. " "I" COID frequently occurs in association with chronic bowel, thyroid, and joint diseases.' COID patients with such associated systemic diseases need to be investigated for MLO. The search should be conducted on both the orbital and systemic disease.

MLO diseases respond to long-term administration of appropriate antibiotics. ${ }^{27} 28$ Rifampicin was tried in the treatment of MLO experimental mouse disease and it significantly decreased the morbidity and mortality in comparison with untreated infected controls. ${ }^{2 x}$ Rifampicin was subsequently used to treat human MLO uveitis unresponsive to corticosteroids in uncontrolled studies. ${ }^{2 x}$ With prolonged rifampicin administration the ocular inflammation subsided, allowing reduction or discontinuation of corticosteroid. ${ }^{2 x}$ Rifampicin is a broad spectrum intra- 
cellularly acting inhibitor of bacterial DNAdependent RNA polymerase and is safe for prolonged administration. ${ }^{29}$ It seems to be indicated in the treatment of orbital disease where MLO are demonstrated. Empirical administration of rifampicin may be considered in COID patients where MLO cannot be excluded by transmission electron microscopy of tissue leucocytes and the disease is progressive.

The authors are grateful to the physicians and technical staff of the Edward S Harkness Eye Institute. Columbia-Presbyterian Medical Center, New York. NY, whose co-operation enabled them to conduct this investigation.

\section{References}

1 Jakobiec FA, Font RL. Noninfectious orbital inflammation. In: Spencer WH, Font RL. Green WR. Howes EL, Jakobiec FA, Zimmerman LE, eds. Ophthalmic pathology. 3rd ed. Philadelphia: Saunders, 1986: 3: 2765-812.

2 Johnson LA. Wirostko E. Chronic idiopathic vitritis: ultrastructural properties of bacteria-like bodies within vitreous leukocyte phagolysosomes. Am J Clin Pathol 1986: 86: $19-24$.

3 Johnson L, Wirostko E. Wirostko B. Chronic idiopathic vitritis: cytopathogenicity of unusual bacteria for vitreous polymorphonuclear leukocytes. I Submicrosc Cytol 1987; 19: 161-6.

4 Wirostko E. Johnson L. Wirostko W. Chronic leucocytoclastic bacterial vitritis: a lymphocyte transmission electron microscopic study. J Submicrosc Cytol 1987; 19: 651-6.

5 Wirostko E, Johnson L, Wirostko W. Chronic intracellular leucocytoclastic bacterial vitritis: a transmission electron microscopic study of the monocytes. J Submicrosc Cytol Pathol 1988: 20: $463-70$.

6 Johnson L, Wirostko E, Wirostko W. Crohn's disease uveitis: parasitization of vitreous leucocytes by mollicute-like organisms. Am J Clin Pathol 1989; 93: 259-64.

7 Wirostko E, Johnson LA. Wirostko BM. Transmission of chronic idiopathic vitritis in mice by inoculation of human vitreous containing leucocyte phagolysosomal bacteria-like bodies. Lancet 1986; ii: 481-3.

8 Wirostko E, Johnson L. Wirostko W. Mouse exophthalmic chronic orbital inflammatory disease. Virchows Arch (A) 1988: 413: $349-55$.

9 Johnson L, Wirostko E, Wirostko W. Mouse lethal cardiovascular disease: induction by human leucocyte intracellular mollicutes. BrJ Exp Pathol 1988; 69: 265-79.

10 Wirostko E, Johnson LA, Wirostko WJ. Mouse interstitial lung disease and pleuritis induction by human mollicute-like organisms. Br J Exp Pathol 1988; 69: 891-902.

11 Freundt EA, Edward DG. Classification and taxonomy. In: Barile MF, Razin S, eds. The mycoplasmas. New York: Academic Press, 1979 1: 1-41.
12 Starr MP. Foreward. In: Whitcomb RF, Tully JG, eds. The mycoplasmas. New York: Academic Press, 1979: 3: xi-xiv.

13 Saglio PMH, Whitcomb RF. Diversity of wall-less prokaryotes in plant vascular tissue, fungi, and invertebrate animals. In: Whitcomb RF, Tully JG, eds. The Mycoplasmas New York: Academic Press, 1979: 3: 1-36.

14 Boatman ES. Morphology and ultrastructure of the Mycoplasmatales. In: Barile MF, Razin S, eds. The mycoplsmas. New York: Academic Press, 1979: 1: 63-102.

15 Rodwell AW, Mitchell A. Nutrition, growth, and reproduction. In: Barile M, Razin S, eds. The mycoplasmas. New York: Academic Press, 1979: 1: 103-40.

16 Smith PF. The composition of membrane lipids and lipopolysaccharides. In: Barile M, Razin S, eds. The mycoplasmas. New York: Academic Press, 1979: 1: 232-57.

17 Barile MF. Mycoplasma-tissue cell interactions. In: Barile M, Razin S, eds. The mycoplasmas. New York: Academic Press, 1979: 2: 425-74.

18 Clyde WA. Mycoplasma pneumoniae infections of man. In: Tully J, Whitcomb R, eds. The mycoplasmas. New York: Academic Press, 1979: 2: 275-306.

19 Cassell GH, Hill A. Murine and other small-animal mycoplasmas. In: Tully J, Whitcomb R, eds. The mycoplasmas. New York: Academic Press, 1979: 2: 235-73.

20 Fernald GW. Humoral and cellular immune responses to mycoplasmas. In: Tully M, Whitcomb R, eds. The mycoplasmas. New York: Academic Press, 1979: 2: 399-423.

21 Horne RW. Comparison between the structure of animal and plant mycoplasmas: extracellular and intracellular morphology. In: Pathogenic mycoplasmas. Amsterdam: Associated Scientific Publishers, 1972: 39-66.

22 Bove JM. Mycoplasma infections of plants. Isr J Med Sci 1981; 17: $572-85$.

23 Ulanova EF. Changes in the nuclei and chloroplasts in cells of big bud-infected tomatoes. Biol Bull Acad Sci USSR 1978; 5: 232-5.

24 Arora YK, Sinha RC. Enzymatic activities in cell fractions of mycoplasmalike organisms purified from aster yellows-infected plants. J Bacteriol 1985; 164: 811-5.

25 Marchesi VT. Chronic inflammation. In: Kissane JM. ed. Anderson's pathology. 8th ed. St Louis: Mosby, 1985: 1: 43-7.

26 Marmont AM, Damasio E, Zucker-Franklin D. Neutrophil metabolism. In: Zucker-Franklin D, Greaves MF, Grossi CE, Marmont AM, eds. Atlas of blood cells-function and pathology. 2nd ed. Philadelphia: Lea and Febiger, 1988: 1: 188-90.

27 Sinha R. Chemotherapy of mycoplasmal plant diseases. In: Whitcomb R. Tully J, eds. The mycoplasmas. New York: Academic Press, 1979: 3: 310-35.

28 Wirostko E, Johnson L. The induction of mouse uveitis by human idiopathic uveitis aqueous humor and treatment by certain anti-tuberculous drugs. Trans NY Acad Sci ser 2, 1974; 36: 693 .

29 Mandell G, Sande M. Rifampin. In: Gilman A, Goodman L, Rall T, Murad F, eds. The pharmacological hasis of therapeutics. 7th ed. New York: MacMillan, 1985; 1202-5.

Accepted for publication 25 May 1989. 